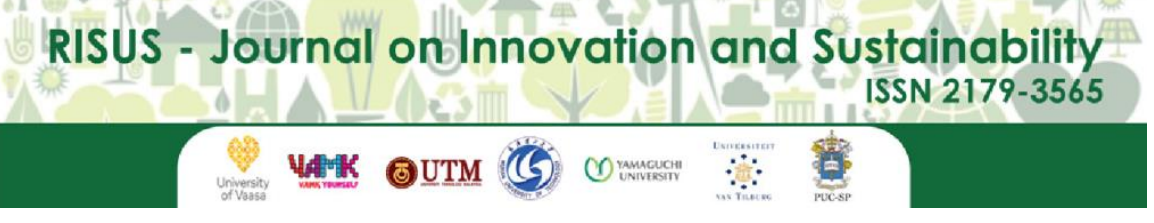

RISUS - Journal on Innovation and Sustainability volume 11, número 4 - 2020

ISSN: 2179-3565

Editor Científico: Arnoldo José de Hoyos Guevara Editor Assistente: Rosa Rizzi

Avaliação: Melhores práticas editoriais da ANPAD

\title{
INHERITANCE AND INNOVATION, ADJUSTMENT AND ACCUMULATION:ON THE MODERNIZATION THINKING OF CHINESE TRADITIONAL CULTURE FROM THE DEVELOPMENT OF THE CULTURAL AND CREATIVE INDUSTRY OF THE FORBIDDEN CITY
}

Herança e inovação, ajuste e acumulação: sobre a modernização do pensamento da cultura tradicional chinesa a partir do desenvolvimento da indústria cultural e criativa da cidade proibida

\author{
Zhu Meifan, Ai Wenjing \\ School of Marxism, Wuhan University of Technology, \\ E-mail: 975212912@qq.com,1043737405@qq.com
}

\begin{abstract}
General Secretary Xi Jinping put forward in the report of the Nineteenth National Congress a new era topic of creative transformation and innovative development of Chinese traditional culture, which put forward higher requirements for the modernization of Chinese traditional culture. The modernization of traditional culture has always been an important part of building a socialist modernization country in an all-round way, but in the process of modernization, cultural modernization, especially the modernization of traditional Chinese culture, has been shackled. Cultural industry, especially cultural creative industry, is an important model for the development of cultural modernization. Its development course provides an important experience for the modernization of Chinese traditional culture. Starting from the symbol cultural creative industry of the Palace Museum, this paper analyses the process of innovative development and creative transformation of Chinese traditional culture, focusing on the realistic dilemma of Chinese traditional culture. What is it, how to develop the modernization of Chinese traditional culture and how to guarantee the modernization of Chinese traditional culture are discussed in order to promote the modernization of Chinese traditional culture.
\end{abstract}

Keywords: Inherit, Innovate, Chinese traditional culture, Modernization, Cultural Creation of the Palace Museum. 


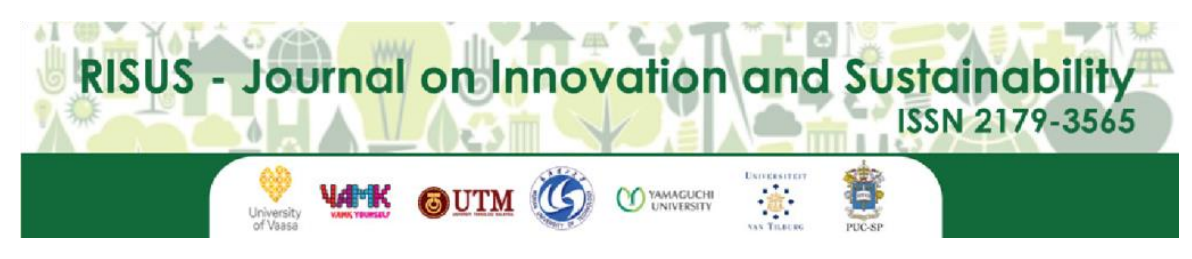

RISUS - Journal on Innovation and Sustainability volume 11, número 4 - 2020 ISSN: $2179-3565$

Editor Científico: Arnoldo José de Hoyos Guevara Editor Assistente: Rosa Rizzi

Avaliação: Melhores práticas editoriais da ANPAD

\title{
HERANÇA E INOVAÇÃO, AJUSTE E ACUMULAÇÃO: SOBRE A MODERNIZAÇÃO DO PENSAMENTO DA CULTURA TRADICIONAL CHINESA A PARTIR DO DESENVOLVIMENTO DA INDÚSTRIA CULTURAL E CRIATIVA DA CIDADE PROIBIDA
}

Inheritance and innovation, adjustment and accumulation: on the modernization thinking of Chinese traditional culture from the development of the cultural and creative industry of the Forbidden City

\author{
Zhu Meifan, Ai Wenjing \\ School of Marxism, Wuhan University of Technology, \\ E-mail: 975212912@qq.com,1043737405@qq.com
}

\section{RESUMO}

O Secretário-Geral Xi Jinping apresentou no relatório do XIX Congresso Nacional um tópico da nova era de transformação criativa e desenvolvimento inovador da cultura tradicional chinesa, que apresentou requisitos mais elevados para a modernização da cultura tradicional chinesa. A modernização da cultura tradicional sempre foi uma parte importante da construção de um país de modernização socialista de uma maneira geral, mas no processo de modernização, a modernização cultural, especialmente a modernização da cultura tradicional chinesa, foi algemada. A indústria cultural, especialmente a indústria criativa cultural, é um modelo importante para o desenvolvimento da modernização cultural. Seu curso de desenvolvimento proporciona uma experiência importante para a modernização da cultura tradicional chinesa. Partindo da indústria cultural criativa de símbolos do Museu do Palácio, este artigo analisa o processo de desenvolvimento inovador e transformação criativa da cultura tradicional chinesa, enfocando o dilema realista da cultura tradicional chinesa. O que é, e como desenvolver a modernização da cultura tradicional chinesa e como garantir a modernização da cultura tradicional chinesa são discutidos para promover a modernização da cultura tradicional chinesa.

Palavras-chave: Herdar, Inovar, Cultura tradicional chinesa, Modernização, Museu de Criação Cultural do Palácio. 


\section{INTRODUCTION}

The report of the 19th National Congress clearly pointed out: "The overall task of the socialist ideology with Chinese characteristics in the new era is to realize socialist modernization and the great rejuvenation of the Chinese nation." (Xi Jinping, 2017) China's excellent traditional culture is an uninterrupted cultural heritage, which shines with the wisdom of the Chinese people of all nationalities, also highlights the great innovation and creativity of the Chinese nation. The modernization of China's excellent traditional culture is also an important means of inheriting innovation and promoting Chinese traditional culture and enhancing the overall strength of culture. It is an important part of the great rejuvenation of the Chinese nation. As the largest museum of ancient culture and art in the world, the Palace Museum is the main carrier of the development of Chinese excellent traditional culture and an important window for Chinese traditional culture to go global. In recent years, the cultural and creative industries led by the Forbidden City have developed rapidly, breaking through one billion turnover in a very short period of time, and making the "Forbidden City Cultural Creation" a well-known brand. Its rapid development not only represents the vigour and vitality of Chinese traditional culture, but also provides a creative development path for the modern Chinese traditional culture to modernize.

This paper takes the Chinese Journal Full-text Database (CNKI) as a sample, and searches for 917 documents with the theme of "Chinese Traditional Culture Modernization". A total of 6457 documents (as shown in Figure 1) are searched for "Cultural Creative Products". It is from the field of modernization of Chinese traditional culture or cultural and creative products as research objects. The academic research has been very thorough, but the number of documents searched for common themes by "Chinese traditional culture" and "cultural creative products" is only 117. The result of this comparison is very unexpected. Through the analysis of these 117 documents, it can be seen from the research level (Figure 2) that the proportion of basic research (social science) and industry guidance (social science) is higher among the two subjects, but Less in policy research and basic applications. For example, Zhang Jing's "Sinicization of Marxism and Cultural Modernization of China" in Nankai University, through reviewing and comparing the development process of Chinese cultural modernization, deeply shows the relationship between Marxism and Chinese excellent culture and foreign culture in the process of Chinese cultural modernization. It holds that the modernization of Chinese culture cannot be separated from the critical inheritance and innovation of Chinese traditional culture and foreign culture, which requires both national characteristics and world vision (Zhang Jing, 2012). Fu Yan of Tianjin Normal University, in her book The Application of Chinese Traditional Culture in the Process of Socialist Modernization, believes that from the contemporary perspective, Chinese traditional culture cannot directly lead to modernization, but China's modernization cannot be separated from the modernization of traditional culture. The evolution of Chinese traditional culture since modern times tells us that the present of culture Modernization must be based on the modernization of economy. The relationship between them is dialectical unity (Fu Yan, 2012).

Figure 1: Overall Trend Analysis Chart of CNKI Key Words Publication Quantity

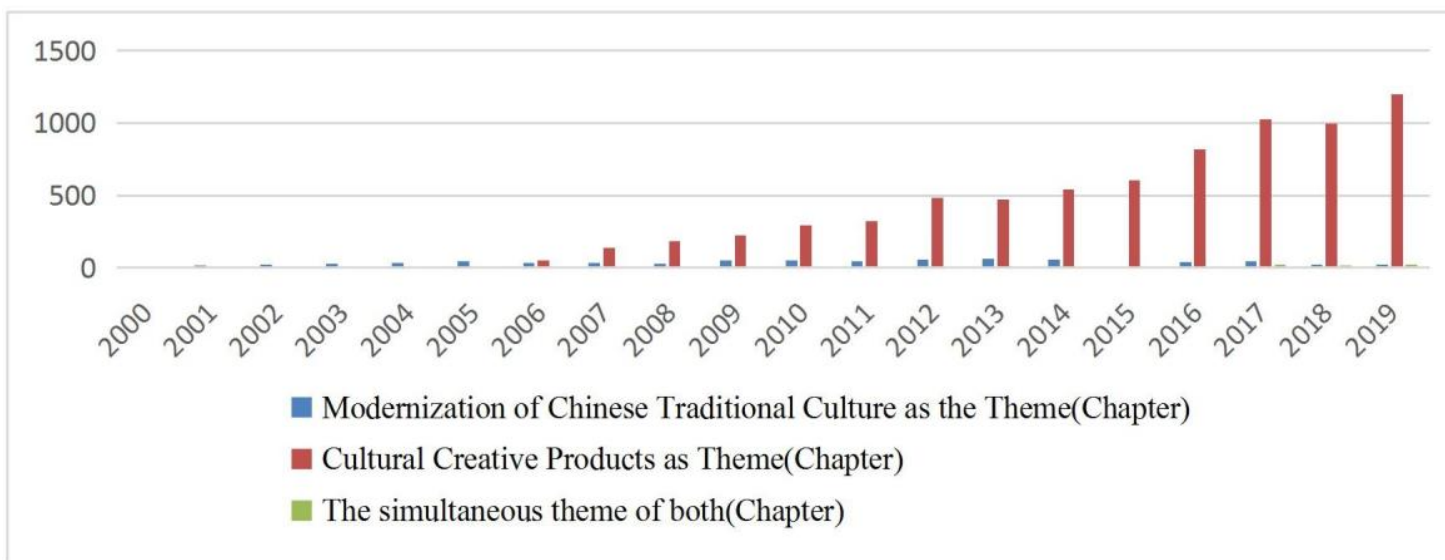


Figure 2: Research Level Distribution Map of CNKI Related Documents

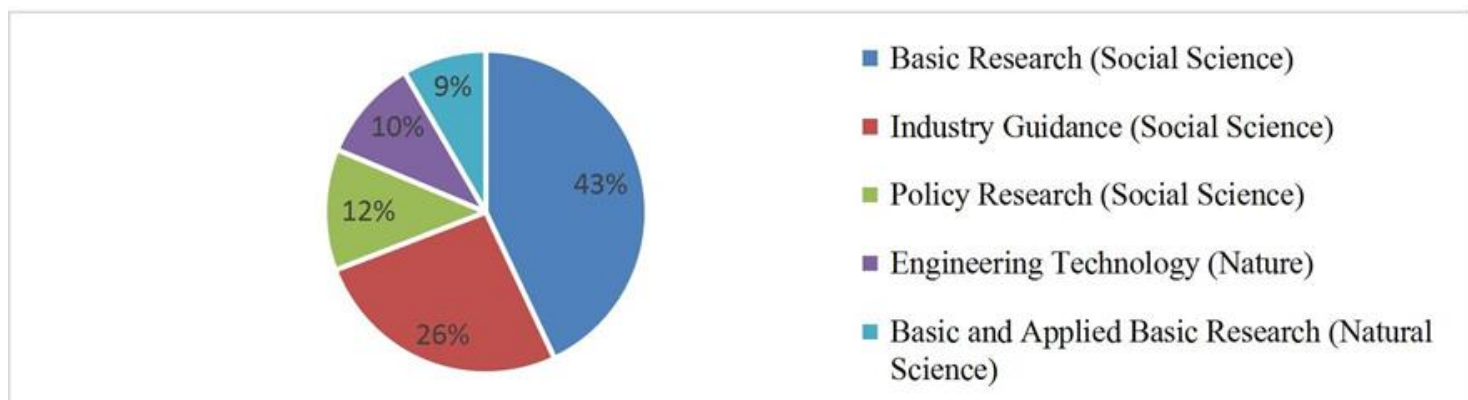

Searching for "cultural creative products" as a key word, a total of 1051 documents were retrieved, and 200 articles were selected through subjective sorting (see Figure 3). It was found that the proportion of philosophy and humanities and social sciences was very high. but through specific analysis, it will be found that the current research on cultural and creative products in the academic circles mostly stays in the art and other majors, focusing on the microscopic aspects of the research and development of cultural and creative products and product development, and the social impact on cultural and creative products. There is still very little research on the forces and the construction of socialist culture with Chinese characteristics. The role of cultural and creative industries in economic construction has become more and more prominent, just as Zhang Qiang, from the Institute of Geographic Science and Resources, Chinese Academy of Sciences, put forward in his article "The Present Situation, Layout and Development Strategy of Cultural and Creative Industries in Chinese Cities", that the cultural and creative industries in Chinese cities are developing rapidly and continuously, and have become the branches of the economy of big cities. The new impetus of pillar industry and transformation development has initially formed six cultural and creative industry clusters, as well as four spatial layout modes of central city, periphery of central city, adjacent high-tech parks and suburban counties (districts). (Zhang Qiang,2013)

Figure 3: Subject Distribution Map of CNKI Related Documents

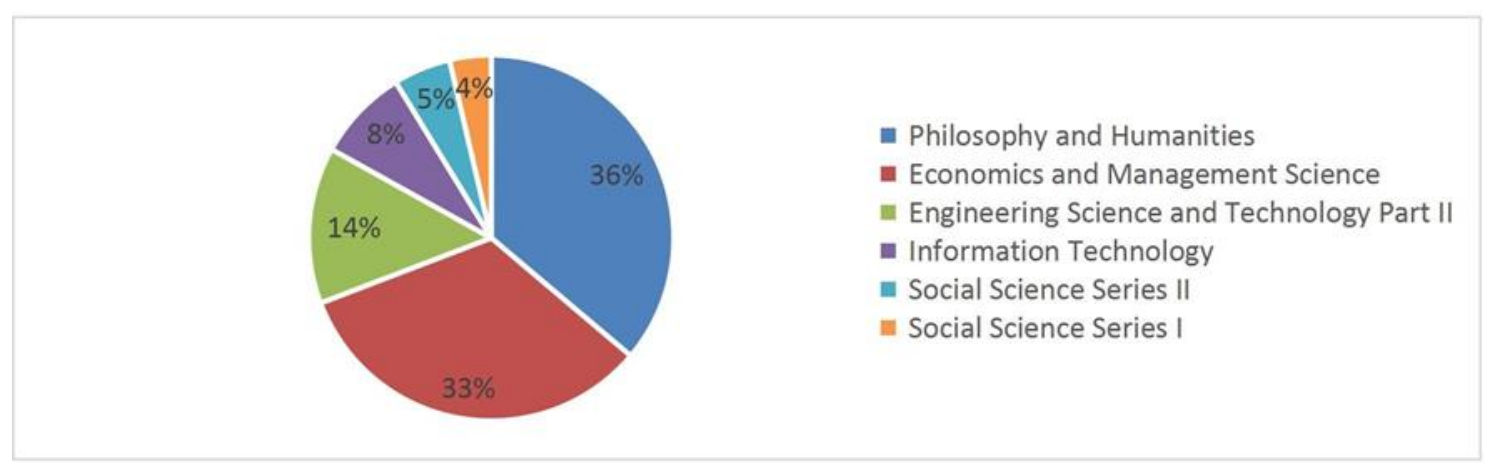

In summary, the level of research and the distribution of disciplines, it is not difficult to conclude that on the basis of the existing literature, there are still many studies on Chinese traditional culture and cultural modernization, and the depth and breadth of research are also very Appreciable; the research on cultural and creative products has also shown a sharp increase in the past decade, and the research on cultural and creative products is also constantly deepening. On the one hand, with the advent of the new era, the construction of socialist culture with Chinese characteristics has entered a new historical orientation, and new research has emerged on the modernization of Chinese traditional culture. On the other hand, although research on cultural and creative products has been made. The depth and breadth of the culture are still deepening on the continuous development of the cultural industry, its position in economic development is deepening, and the development of cultural and creative industries needs to be deepened, and it is mentioned at the height of 
promoting a strong socialist culture. To further address the importance of the cultural and creative industries, thus providing a new development path for the development of China's special socialism.

\section{THE DILEMMA OF THE MODERNIZATION OF CHINESE TRADITIONAL CULTURE}

Chinese traditional culture is deeply rooted in the practice of China's five thousand years, and china's vast land. It contains the strong emotional sustenance and spiritual pursuit of the Chinese nation and is the unique emotional bond and spirit of the Chinese nation. In the face of the ever-changing technological development, the process of modernization is getting faster and faster, the pace of China's transition to a modernized country is getting bigger and bigger, and the process of cultural modernization is constantly improving and developing, but it is still trapped and existing problems.

\subsection{The contradiction between traditional culture and modern culture}

The contradiction between traditional culture and modern culture is an inevitable contradiction in the process of modernization. Some scholars believe that Chinese traditional culture is impossible to modernize, but most scholars hold a positive view. From the definition of culture, culture is the historical imprint of self-development and self-improvement formed by human beings in adapting to nature and transforming nature. Different cultures represent different people's ideas, customs and life in different backgrounds in different historical periods. Chinese traditional culture is the sum of the outstanding cultural achievements of the formation and development of the Chinese nation in all historical periods of China. This represents the existence of the Chinese tradition due to the inevitable existence of differences in different periods and the modernization. The contradiction between tradition and modernity unfolds. Judging from the historical process of China's modernization, China's modernization is not a process of active development, but a passive start. The slogans such as "Beat someone by playing his games only better", "Chinese learning as the fundamental structure, Western learning for practical use " are not only self-examination of their own systems, but also a reflection of the lack of self-confidence and even inferiority for their feudal culture in the early stage of China's modernization. Forming the pattern that the east is subordinate to the west as Marx said. In the process of modernization, the opening poor of china is greater and greater. People are receiving more and more new ideas and concepts, more and more forms, more and more highend means, under the guidance of pluralistic thoughts and values people's way of thinking and behavior practice have changed the transmission of Chinese traditional culture has been impacted and even overthrown. In the modernization process, it is especially important to deal with the relationship between tradition and modernity. In the process of building a socialist culture with Chinese characteristics, based on the reality of modern development, we must handle the relationship between Chinese traditional culture and the relationship between foreign culture and especially Western culture.

\subsection{The problem of how to treat Chinese traditional culture correctly}

The answer to the question is not to return to the basic consensus that is considered in the macro sense - "take its essence, go to its dross", but to return to the microscopic problem of what to "take" what to "go". That is how to deal with the boundary between "essence" and "dross". This issue has also been controversial in Chinese academic circles. Some scholars believe that the generation and disappearance of culture all have their own natural evolution laws. People's understanding and change of culture should be based on the law of respecting the evolution of culture. Correspondingly, some scholars believe that culture is determined by people. Decisions, its evolution and development should be based on human subjective needs and development. 
Regarding the issue of the traditional cultural modernization approach, the academic circles have given three views of "basic affirmation" and "complete reconstruction" and "compromise". Most scholars believe that it is necessary to "take the essence and go to its dross." This has created a new problem: in traditional culture, there are both "essence" and "dross". Does "essence" necessarily apply, and "dross" does not necessarily apply? Is the "essence" always the "essence", and is the "dross" always "dross"? Can the positive factors and the "essence" of traditional culture and the modernization process be equated, and can the negative factors that are not compatible with the modernization process be equal? Even positive factors that are compatible with the modernization process can maintain their enthusiasm in the face of various cultures in the process of modernization?

\section{THE AVENUE OF THE MODERNIZATION OF CHINESE TRADITIONAL CULTURE}

The modernization of Chinese traditional culture is a process of continuous progress. The development process of The Imperial Palace's cultural and creative industries has provided reference for the development of traditional culture modernization. The success of the Palace Culture Creation reflects that the traditional culture modernization must be based on the roots of Chinese excellent traditional culture; Give play to the role of economy, science and technology and the masses of the people; the limitations of The Forbidden City Cultural Creation enlighten the modernization of traditional culture: we must persist in comprehensively deepening the reform of the cultural system, innovating various aspects of the traditional cultural modernization, and injecting vitality into cultural creation.

\subsection{Based on the root of the modernization of traditional culture}

Traditional culture is an important bridge connecting traditional culture and modern society and plays an important role in the process of socialist modernization. General Secretary Xi Jinping mentioned on many occasions that he should fully explore and carry forward the fine traditional Chinese culture. China's excellent traditional culture has a strong vitality, and this vitality will be a powerful driving force for the Chinese nation to prosper and rejuvenate. The modernization of traditional culture must be based on the "root" of excellent traditional culture itself, fully tap its value, strengthen cultural self-confidence, condense the cultural community, and finally drive the process of cultural modernization.

Deeply explore the value connection of Chinese excellent traditional culture. Take the Beijing Palace Museum as an example. The Forbidden City is a unit of ancient Chinese cultural art based on the old Tibetan cultural relics of the Ming and Qing Dynasties. It has collection, research and display functions. The total collection of the museum is more than 1.8 million pieces, mainly involving cultural relics, ancient buildings books and other 25 categories; it is a treasures house of art that cannot be neglected in china and even in the world. The Palace Culture is the most representative of Chinese traditional culture. For the cultural relics of the Palace Museum, it is the icy "objects" displayed in the Forbidden City, all of which are lifeless "empty shells" on the exhibition shelf. In 2013, the creative Design Competition with the theme of "Bringing the Forbidden City Culture Home" brought the Forbidden City culture to the market. So far, the number of products in the Forbidden City has been sung more than 10,000. In 2016, The Forbidden City Cultural Creation earned 1 billion yuan, and in 2017 it reached 1.5 billion. This figure exceeds 1,500 A-share listed companies. The 600-year-old Forbidden City began to become young, and the Forbidden City culture was "lived". The Forbidden City Cultural Creation products from the shelves no one cares to countless powder, this is the success of The Forbidden City Cultural Creation, but also the National Palace for the full excavation of the traditional culture of the Forbidden City, from the tall and the Great Hall of the Temple to the grass in the back garden, The Forbidden City Cultural Creation is known for its unique design philosophy and communication methods. The continuous exploration of the traditional cultural value of the Forbidden City is the source of strength and the foundation of the Forbidden City. It is the foundation of each story. It is the key to the modernization of traditional culture to express the story behind each cultural relic and express the past and present life of cultural relics. 
Strengthen cultural confidence in traditional culture. Churchill once had a famous saying: I would rather lose an Indian than lose a Shakespeare. This should be an important expression of the importance of traditional culture. General Secretary Xi Jinping pointed out: "Chinese outstanding traditional culture is the spiritual lifeline of the Chinese nation and a solid foundation for us to gain a firm foothold in the world cultural agitation. We must inherit and promote the Chinese traditional culture in light of the new era conditions." (Xi Jinping, 2014) Based on a deep understanding of Chinese traditional culture, the slogan of CCTV's National Treasures is "This is a young program, how young is it? Up and down five thousand years!" This is a great confidence in Chinese traditional culture. The extremely confident performance, the program created by the Provincial Museum of the United Nations in the Palace Museum of Beijing allows people to more intuitively understand the "previous life" and "this life" of our cultural relics, which is also a perfect presentation of the modernization of traditional culture. The strengthening of culture and going out are based on the deep treasure house of traditional culture. Chinese civilization is the only continuous civilization in the world. This is the result of cultural self- confidence. The inheritance and promotion of traditional culture is the fundamental reason for its continuation. Since the industrialization, Chinese traditional culture has been strongly impacted by Western advanced culture. However, in the long history of history, this setback is only a small wave. The Chinese civilization of 5,000 years is still luminescence, giving the Chinese nation a steady stream of self-confidence.

Correctly handle the relationship between traditional culture and modern culture. The contradiction between traditional culture and modern culture is not irreconcilable. The principle of "creative transformation and innovative development" proposed by General Secretary Xi Jinping is the correct methodology for solving the contradiction. Transforming and innovating on the basis of the positive inheritance of Chinese traditional culture. The creative transformation emphasizes breaking free from the traditional culture, based on the actual needs, guiding the positive elements in the traditional culture, and transforming with the requirements of the new era development; Innovative development refers to the improvement and transcendence of excellent traditional culture. Innovation and development on the basis of solving problems based on reality. In this principle, traditional culture is the foundation, development is the pursuit, innovation is fundamental (Wan Guangxi, 2017). The Palace Museum profoundly excavated the cultural value of the Forbidden City collection, and implanted the traditional cultural elements of the Forbidden City into the fashionable and trendy modern handicrafts, so that the excellent cultural traditions and fashions can be perfectly combined, express the service concept of Bring the Palace Museum Home through the carrier of cultural products. Let more people understand and love the Forbidden City culture through cultural products, as well as the traditional Chinese culture represented by the Forbidden City culture. On the basis of creative design, The Forbidden City Cultural Creation actively participates in cultural and creative learning exchange forums and exhibitions at home and abroad, and sends the Forbidden City culture out of the country in rich cultural exchange activities, breaking the boundaries of national culture and making the Forbidden City culture a "public property".

\subsection{Highlighting the power of traditional cultural modernization}

As a kind of soft power, culture has become more and more important in international competition. The "Cultural Policy for Development" conference held in 1998 clearly stated that "the world economic development is ultimately defined by cultural concepts, and cultural prosperity is the highest goal of development (Shen Zhuanghai,2008). The cultural industry presents its indispensable influence with a new economic growth. The two sources of power that cannot be ignored in the process of cultural modernization are the power of economy, science and technology, and the people.

Show the "economic power" of cultural modernization. Compared with the rapid and efficient characteristics of modern culture, traditional culture is long and soft, and there is a sense of "powerlessness" in today's market economy. In the process of modernization of traditional culture, we must pay attention to the development of cultural productivity. The core part of cultural productivity is the cultural industry. The most important contribution to the cultural industry is the cultural and creative industry. As a pillar industry of the tertiary industry, the value-added of national culture and related industries in 2017 was 3.5462 trillion yuan, accounting 
for $4.29 \%$ of GDP, of which Beijing accounted for 14.3\%. In the 13th Beijing Expo, $20 \%$ of the 39 cultural and creative industries that signed the 6.8 billion yuan project were mixed cultural projects. The Palace Museum is a representative of traditional culture and modern culture. According to a survey of purchasers of The Forbidden City Cultural Creation products, $70 \%$ are women, $70 \%$ are after $80 \mathrm{~s}, 90 \mathrm{~s}$, and $80 \%$ of purchasing power is below 200. In view of this feature, Forbidden City can be described as shoot the arrow at the target, The Forbidden City Cultural Creation has developed Silk, pottery, porcelain, bronze, wooden, and other materials, paintings, key chains, pens, T-shirts, jewelry, ties, bags, umbrellas, houses, dolls, make-up, and other different products, more than 10,000 kinds It involves all aspects of life, not only for consumers to be willing to consume but also for consumption. A good cultural and creative product should be to facilitate the daily life of the people, reflect the traditional values of Chinese culture, and spread the story of China. It's not surprising that billions of sales legends. At the same time, on the basis of the full realization of economic benefits, the National Palace Museum has also placed social benefits in the first place. Yuxiang Shan, former director of the Beijing Museum, said in an interview: "The mission of the Forbidden City is not just to make money. In 2018, the National Palace Museum held more than 60,000 educational activities, and went to many countries around the world without collecting a penny. A large part of the money for public welfare and education comes from the income of The Forbidden City Cultural Creation" As a public cultural service unit, the Palace Museum is at the forefront of the modernization of traditional culture.

Perform the "scientific and technological power" of culture modernization. The most striking feature of modernization is the rapid development of science and technology. As the primary productive force, science and technology have greatly improved production efficiency and promoted rapid economic development. Its role has greatly exceeded the role of capital and labor in economic transformation. The Forbidden City Cultural and Cultural Achievements will be fully demonstrated. In product research and development, Forbidden City has independently developed and launched three Ipad applications: "The Beauty of the Man", "The Forbidden City Auspicious omen" and "The Emperor's Day". In the collection display, six films were shot using virtual reality technology. It will also rely on the Duanmen Digital Museum, the "Firmament Tower" Digital Cinema, the Great High Hall Digital Museum and the National Museum of the Imperial Palace. Through the real reproduction of the film, let the audience feel the glamour of the Forbidden City culture, and taste the depth of the Forbidden City culture in the details. At the time of the $5 \mathrm{G}$ discussion, the Forbidden City decisively signed a strategic cooperation agreement with Huawei to allow 5G to enter the museum to provide technical support for the "Digital Palace" and further promote the digitalization, informatization and intellectualization of the Palace Museum.

Manifest the "people's power" of cultural modernization. General Secretary Xi Jinping emphasized that "literary and artistic creation, philosophical and social science research must first understand the question of who to create and who to speak for. This is a fundamental problem." (Xi Jinping,2019) The people are the source of creation for cultural workers, only rooted in the people, entering Practice, express the voice of the people, serve the people is the vocation of the literary and art workers. The Forbidden City Cultural Creation always adheres to the people-centered and demand-oriented. From the history of the Forbidden City, it is not difficult to see that the real fire of the Forbidden City is the Cultural Creative Design Competition held in 2013. Before this, The Forbidden City Cultural Creation mainly carried out activities under the symbol of "Forbidden City", only considering the cultural, historical and aesthetic functions of the product have resulted in a series of cultural products that are uninteresting and non-practical, and naturally will be left out. After 2013, The Forbidden City Cultural Creation began to collect cultural product ideas from the public, so that the products are really close to life, close to the people, like the "Forbidden City Calendar", "Chaozhu-style headphones" and "Queen's Tea Cup" in the Forbidden City Cultural Creation. It indicates that the needs of the people are the orientation of culture. The Forbidden City Cultural Creation bears the dual responsibility of inheriting culture and spreading culture. For product research and development, it must be designed and created from the perspective of the people. The most common objects in people's lives, such as headphones, calendars, teacups, wall clocks, etc., serve as carriers and then break into the basic elements of traditional culture in the Forbidden City. It not only gets rid of the rigid image of the old "souvenir" that used to talk about cultural attributes, but also adds the interesting, innovative and functional needs of the people, which makes the traditional culture more "existent" in people's daily life. "Only 
when they are needed by the people, the cultural relics have dignity and this is also the ultimate goal of cultural relics protection."

\section{THE INSTITUTION OF THE MODERNIZATION OF CHINESE TRADITIONAL CULTURE}

The report of the 19th National Congress pointed out that "culture revitalizes the country and prospers cultural strengthens the nation and strengthens" (Xi Jinping, 2017), and the cultural construction of socialist modernization requires the establishment of a world-class c-Korea. Traditional culture is the source of Chinese culture that has lasted forever and youthful vitality. To build a strong cultural strong country and accelerate the pace of modernization of traditional culture, we must accelerate the reform of the cultural system.

Since the reform and opening up, especially since the 16th National Party Congress, China's cultural system reform has achieved initial results. However, some deep-seated contradictions that restrict cultural development still exist. At the Third Plenary Session of the 18th CPC Central Committee, Comrade Xi Jinping put forward the "age strategy of comprehensively deepening reforms", stressing "adhering to the people-centered work orientation, insisting on putting social benefits first, and integrating social and economic benefits. Inspire the whole culture to create vitality as the central link, and further deepen the reform of the cultural system."97

The most important thing in the reform of the cultural system is to establish and improve the modern cultural market system. The cultural market is the sum of various cultural production relations in the process of cultural resources exchange between producers, operators and consumers. It has four functions: one is the resource configuration function. Strengthen the socialist culture's great development and prosperity by giving play to the decisive role of the market in resource allocation; the second is to balance supply and demand. The cultural market can objectively reflect and coordinate the relationship between market supply and demand; the third is creative transformation. The creativity and wisdom that will be condensed in cultural products are expressed in the form of materialization; the fourth is the function of value communication, that is, the transmission and transformation of cultural creativity through the exchange and consumption of cultural products, which is a process of creating, transferring and realizing value. The cultural market combines the commodity economic attributes of the general commodity with the unique ideological attributes of the culture itself.

The development of the current cultural market has achieved gratifying results. In 2016, the Ministry of Culture issued a series of policies and regulations on cultural development, such as the "Notice on Promoting the Development of Cultural and Creative Products in Cultural and Cultural Relics Units" and "Publicities of the People's Republic of China" Cultural Service Guarantee Law, the Public Library Law of the People's Republic of China, etc. Taking the Forbidden City Cultural Creation as an example, the document "Notice on Promoting the Development of Cultural and Creative Products for Cultural Relics Units" is of great significance in exploring the cultural resources of museum collections, developing cultural and creative industries, exploiting cultural and creative products, and promoting excellent traditional culture, and inheriting Chinese Civilization. The document expands cultural and cultural relics units, promotes the combination of cultural resources and cultural production and life, and encourages cultural relics units to cooperate with social forces. Under the guidance of the policy, the prosperity and development of The Forbidden City Cultural Creation has made great contributions to enhancing the vitality of the market. However, there are still many shortcomings in the development of the cultural market, such as insufficient exploration of cultural consumption potential, insufficient supply of high-quality culture, numerous and chaotic market players, fierce homogenization competition, and insufficient protection of cultural intellectual property rights. For example, the development path of The Forbidden City Cultural Creation is not smooth sailing. When the "Changxin Pajamas" designed with the elements of the Changyue Pavilion, the bat pattern and the Qing Dynasty's old Tibetan costumes are still in the crowd funding, Plagiarism and imitation goods are already on the line and crowd funding; the flooding of the Forbidden City lipstick in the online sales platform; the public's confusion on the flagship store of the Forbidden City and the misfortune of the Forbidden City Tabaco all showed the problems of the imperfect protection system of cultural property rights and the ineffective supervision of the network market. 


\section{CONCLUSION}

If Chinese traditional culture wants to accomplish modernization, it must inherit and carry forward the excellent traditional culture of China. It is not only to refine and innovate the unique spiritual signs in traditional culture, but also to innovate based on inheritance and inherit in innovation, so that Chinese traditional culture can promote the construction of a powerful socialist modernization country. Only in this way can we serve the great rejuvenation of the Chinese nation. The creation of Palace Museum prose epitomizes the process of modernization of Chinese traditional culture. Its success and misunderstanding provide experience and lessons for the road of modernization of Chinese traditional culture in the new era. They all add value to the building of a powerful socialist cultural country in an all-round way and a powerful socialist modernization country in an allround way.

\section{Acknowledgement}

This paper is supported by Ministry of Education 2016 Chinese Excellent Cultural and Art Inheritance Project (444-11075).

\section{REFERENCES}

HAO, Lixin, ZHU, Ziwei. The Era Situation and Value Choice of Socialist Culture with Chinese Characteristics - On the Important Exposition of General Secretary Xi Jinping on Strengthening Cultural Confidence [J]. Mao Zedong Deng Xiaoping Theory Research, (11):1-7+107(In Chinese), 2018.

HUI, Ming. The concept and practice of cultural powers [M]. Social Sciences Academic Press, 134 (In Chinese), 2013.

LI, Jianjun, LIU, Cheng, LI , Lei, MA, Ruixue. Promoting the Modernization of Xinjiang Traditional Culture with Cultural Confidence [J]. Journal of Xinjiang Normal University (Philosophy and Social Sciences), 39(03):65-76 (In Chinese), 2018.

LI, Tengkai. The Modernity Logic of Marx's Practice and the Modernization of Chinese Traditional Culture [J]. Hubei Social Sciences, (06):5-12 (In Chinese), 2017.

LIANG, Shurong, HOU ,Jie. The Social Effect of the Forbidden City Cultural Creation Products- Taking the Forbidden City Calendar as an Example [J]. Journal of Baicheng Teachers College,32(09):20-26 (In Chinese), 2018.

LIU, Lintao. The Concept, Essential Characteristics and Contemporary Value of Cultural Confidence [J]. Thought Education Research, (04):21-24 (In Chinese), 2016.

SHAN, Li. Chinese excellent traditional culture is the basis of cultural self-confidence [J]. People's Forum, (35):134-135 (In Chinese), 2018.

SHEN, Zhuanghai. Real Power of Soft Culture: Why to Improve the Soft Power of National Culture [M]. People's Publishing House, 12 (In Chinese), 2018. 
WAN, Guangxia. A Philosophical Survey of the Innovative Development of Creative Transformation of Chinese Traditional Culture [J]. Dongyue Theory, 38(09):27-34(In Chinese), 2017.

XI, Jinping. A country, a nation cannot have no soul [J]. Xinxiang Review, (10):6-8 (In Chinese), 2019.

XI, Jinping. Adhere to the people-centered creative orientation to create more outstanding works worthy of the times [N]. People's Daily, 10-16:1 (In Chinese), 2014.

XI, Jinping. Decisive victory to build a well-off society in an all-round way to win a great victory in socialism with Chinese characteristics in the new era - Report at the 19th National Congress of the Communist Party of China [N]. People' s Daily, 10-18:1 (In Chinese), 2017.

XIA, Zhenkun, Tang Long. On Traditional Culture and China's Modernization [J]. Chinese Culture Forum, (02):100-105 (In Chinese), 2005.

XU, Yuhua. Analysis of Xi Jinping's Cultural Modernization Thought in the New Era [J].Study Theory, (08):9-10 (In Chinese), 2018.

ZHUANG, Zi. Hundred Collections of Chinese Classical Books: Zhuangzi [M], Yunnan: Yunnan People's Publishing House, 17 (In Chinese), 2011.

ZHANG, Jing. Sinicization of Marxism and Modernization of Chinese Culture [M]. Tianjin: Nankai University Press, 10 (In Chinese), 2012.

ZHANG, Qiang. Current situation, layout and development strategies of urban cultural and creative industries in China [J].Progress in Geographic Science, 32(08):1227-1236 (In Chinese), 2013.

ZHANG, Yaqi, KE, Ping. The Status Quo and Enlightenment of the Development of Cultural Creative Products in American Libraries [J]. Library and Information Service, 61(22):59-68 (In Chinese), 2017. 